\title{
EVALUASI TERHADAP PERUBAHAN STATUS BEBERAPA HARA TANAH SETELAH 10 TAHUN DI BUKIT GAJABUIH PADANG
}

\author{
Hermansah, Juniarti, dan Utami Maya Pribadi \\ J ur.Tanah F akultas Pertanian U nand
}

\begin{abstract}
This experiment is about the evaluation of characteristic alteration of soil nutrients after ten years at tropical rain forest Bukit Gajabuih Gunung Gadut Padang. This experiment was conducted from November 2006 - April 2007. This experiment is arranged based on anova design with three treatments which was based on three great groups of land (oxic-dystroudept (eutriccc, aquic), oxicdystroudept (xanthic), oxic-typic-dystroudept (xanthic)). The purpose of this experiment was to study the alteration of soil fertility characteristics $(\mathrm{K}, \mathrm{Ca}, \mathrm{Mg}, \mathrm{Na}, \mathrm{P}$ and $\mathrm{C} / \mathrm{N}$ ) in ten years period (1995-2005) in tropical rain forest at Bukit Gajabuih Padang, to observe vegetation variety alteration, and the relationship with the land fertility characteristics. From the experiment was found that nutrient status of the soils altered after ten years $(* 1995-2005)$. Available P content increased about $77 \%$, exchangeable $\mathrm{Na}$ and $\mathrm{K}$ increased $86,04 \%$ and $53.65 \%$, respectively. On the other hand, exchangeable $\mathrm{Mg}$ and $\mathrm{Ca}$ decreased 3,05\% and 65,88\%, respectively. Land $\mathrm{C} / \mathrm{N}$ ratio decreased about $21,39 \%$. The experimental plot had low soil $\mathrm{pH}$.
\end{abstract}

Key Words: tropical rain forest, soil nutrient status

\section{PENDAHULUAN}

Perubahan penutupan tanah oleh vegetasi akan menyebabkan terjadinya perubahan daur ulang unsur hara kedalam tanah. Hal ini akan mengakibatkan terjadinya ketidakseimbangan ekosistem hutan khususnya kualitas tanah (Hermansah et al, 2003).

Penelitian tentang dinamika hutan dan tanah di hutan hujan tropis telah banyak dilakukan di Sumatra Barat, tepatnya di Gunung Gadut, Bukit Gajabuih Padang. Di daerah ini telah dibuat plot observasi Ekologi hutan dan tanah sejak tahun 1998 oleh beberapa ilmuwan Jepang dan ilmuan Universitas Andalas. Karakterisasi tanah di daerah penelitian bukit Gajabuih ini telah dilakukan oleh Kubota (1999), baik secara vertikal maupun horizontal. Penelitian tersebut berkesimpulan bahwa karakteristik tanah diplot penelitian ini sangat beragam dan berkolerasi positif dengan keragaman tumbuhan.

Plot penelitian ini berada pada ketinggian antara 500-595 dpl. Plot 1 ha ini dibagi dalam 100 sub plot dengan ukuran 10m x 10m (Ogino, Hotta, Tamin, Yoneda, 1984). Namun, dalam penelitian ini peneliti hanya mengambil 15 sub plot saja berdasarkan perbedaan janis famili tanah. Meskipun luas plot penelitian hanya 1 ha, dijumpai beberapa jenis famili tanah seperti Oxic-TypicDystroudept (xanthic), oxic-Dystroudept (xanthic) dan Oxic-Dystoudept (eutric, aquic) yang berkembang dari batuan kapur dan memiliki kation-kation basa yang tinggi.

Plot penelitian yang terletak di daerah kota Padang ini telah mengalami perubahan vegetasi yang sangat signifikan, yang disebabkan oleh pebangan hutan oleh masyarakat pada awal reformasi atau akhir tahun 1998, yang menyebabkan daerah ini menjadi terbuka yang ditumbuhi oleh semak belukar. Dengan berubahnya kondisi vegetasi yang signifikan tentu akan menyebabkan terjadinya perubahan karakteristik kesuburan tanah di plot penelitian ini. Kondisi vegetasi yang ada saat ini sangat jauh berbeda dengan keadaan vegetasi 10 tahun yang lalu. Keadaan tersebut diduga akan mempengaruhi karakter 
tanah, baik terhadap sifat fisika tanah, maupun kimia tanah. Untuk menjawab pertanyaanpertanyaan para ahli ekologi tentang interaksi antara tanah dan tanaman maka dilakukan penelitian "Evaluasi terhadap perubahan status beberapa hara tanah setelah 10 tahun di hutan hujan tropis bukit Gajabuih Padang". Tujuan dari penelitian ini adalah :

(1). Mempelajari perubahan karakteristik kesuburan dan cadangan beberapa hara tanah (K, Ca, Mg, Na, P dan C/N) dalam periode sepuluh tahun (1995-2006) di plot observasi ekologi hutan hujan tropis Bukit Gajabuih Padang.

(2).

Mengobservasi perubahan keanekaragaman vegetasi yang berada di bukit Gajabuih Padang, dan hubungannya dengan karakteristik kesuburan tanah.

\section{BAHAN DAN METODA}

Penelitian ini adalah berupa penelitian observasi lapangan. Plot penelitian seluas 1 ha dibagi dalam 100 sub plot yang berukuran $10 \mathrm{~m}$ $\mathrm{x} 10 \mathrm{~m}$. Plot dengan ukuran 1 ha (100 sub plot) ini mempunyai karakteristik kesuburan tanah yang bervariasi (Wakatsuki et al, 1986). Sampel tanah untuk tujuan penelitian ini diambil pada 15 buah sub plot yang ditetapkan berdasarkan perbedaan jenis famili tanah dari sub-sub plot yaitu Oxic- Dystroudept (eutric, aquic), Oxic-Typic-Dystroudept (xanthic), Oxic-Dystroudept (xanthic) yang masingmasing famili tanah tersebut akan diambil 5 buah sub plot. Setiap sub plot tanah akan diambil pada kedalaman 0-20 cm pada 5 titik pengambilan. Untuk dapat memiliki masingmasing sub plot maka sampel diambil dengan cara sampel komposit dengan mengambil 5 titik pada setiap sub plot dan kelima titik tersebut untuk kedalaman yang sama akan digabung jadi satu.

Data yang diperoleh dari hasil analisis hara tanah diperbandingkan dengan data hasil analisis hara tanah yang telah dilakukan oleh Kubota tahun 1995. Kemudian dilihat perubahan-perubahan status haranya yang terjadi selama 10 tahun.

Persiapan

Pada tahap ini dilakukan pengumpulan data sekunder berupa lampiran dan hasil-hasil penelitian yang telah dilakukan oleh Kubota pada tahun 1995 dan pengumpulan informasi tentang daerah penelitian dan menetapkan titik-titik pengambilan sampel tanah. Karena plot penelitian ini telah dipetakan dengan memberi nomor masing-masing sub plotnya maka dalam memantapkan titik pengambilan sampel saya lakukan dengan melihat sebaran jenis famili tanah dan disesuaikan dengan nomor sub plot yang ada. Pada tahap persiapan ini ditetapkan nomor-nomor sub plot yang akan diambil sampelnya. Nomor-nomor sub plot yang diambil adalah 1, 3, 56, 9, dan 51 pada tanah Oxic-Dystroudept (eutric,aquic), sub plot nomor 79, 86, 87, 88 dan 89 pada tanah Oxic-Typic Dystroudept (xanthic), sub plot nomor 23, 42, 48, 70 dan 100 pada tanah Oxic-Dystroudept (xanthic).

Pengambilan sampel tanah

Pengambilan sampel tanah pada 15 buah sub plot berukuran $10 \mathrm{~m} \times 10 \mathrm{~m}$ yang telah ditetapkan pada 3 posisi berdasarkan jenis tanah yaitu oxic-Dystroudept (eutric, aquic), oxic-typic-Dystroudept (xanthic), oxicDystroudept (xanthic) dilakukan dengan menggunakan bor belgi. Sampel tanah diambil pada kedalaman 0-20 $\mathrm{cm}$ secara komposit. Tiap sub plot yang telah ditentukan akan diambil pada 5 titik pengambilan. Sampel tanah yang telah diambil dibawa ke laboratorium untuk keperluan analisis.

Analisis data

Untuk melihat perbedaan karakteristik hara tanah berdasarkan jenis famili tanah, digunakan tabel kriteria sifat kimia tanah dan untuk membandingkan secara statistik antara famili tanah yang ada dilakukan Annova satu 
jalur 5\%. Tabel kriteria sifat kimia tanah sebagai tolak ukur penilaian tinggi atau rendahnya karakteristik hara tanah berdasarkan jenis famili tanah pada daerah penelitian.

Analisis tanah

Analisis yang dilakukan yaitu analisis beberapa kadar hara dan $\mathrm{pH}$ tanah. Adapun jenis-jenis analisis dan metoda yang digunakan nya disajikan pada Tabel 1 . Prosedur analisis dilaboratorium.

\section{HASIL DAN PEMBAHASAN}

\section{Keadaan Umum Plot Penelitian}

Plot observasi ekologi hutan dan tanah telah dibuat oleh Hotta dan Ogino (1981). Plot ini berada di sepanjang lereng bawah sebelah Barat Gunung Gadut yaitu di puncak Bukit Gajabuih. Plot penelitian ini berada pada ketinggian antara 500-595 m diatas permukaan laut (dpl) dan memiliki curah hujan yang tinggi sepanjang tahun.

Hutan hujan tropis di Sumatra Barat umumnya dan Gajabuih Gunung Gadut khususnya, memiliki karakteristik tertentu antara lain : Merupakan daerah peralihan perkembangan bahan induk dengan ditemukannya 3 macam bahan induk tanah yaitu batuan metamorfik, batuan andesit dan batuan kapur (Kubota, 1999). Dan plot penelitian ini memiliki tanah yang sangat heterogen yaitu terdapat 3 tipe sub group tanah diantaranya oxic typic-dystroudept (xanthic), oxic-dystroudept (eutric, aquic), dan oxicdystroudept (xanthic) yang berkembang dari batuan limestone dan memiliki kandungan Aldd, serta kation-kation basa yang tinggi khususnya unsur $\mathrm{Ca}$. Daerah ini menurut (Ogino et al, 1984) merupakan salah satu hutan hujan tropis basah yang terdapat di Sumatra Barat yang pada bagian kaki bukitnya hampir berubah akibat penebangan dan pembakaran hutan serta usaha pertanian seperti sawah, penanaman monokultur antara lain tanaman Pisang, Kelapa, Durian, Anggrek serta spesies lainnya.
Plot penelitian ini berada pada ketinggian antara 500-595 dpl. Plot 1 ha ini dibagi dalam 100 sub plot dengan ukuran $10 \mathrm{~m}$ x 10m (Ogino et al, 1984). Pada plot penelitian ini, pohon yang mempunyai DBH (diameter at breast height/ diameter pohon yang diukur setinggi dada) lebih dari $8 \mathrm{~cm}$ ditemukan sebanyak 346 batang yang terdiri dari 139 spesies yang teridentifikasi dan spesies yang tidak teridentifikasi sebanyak 207 batang. Banyak pohon keseluruhan pada plot penelitian ini adalah 475 batang (Kubota, 1999).

\section{Kondisi Vegetasi disaat Penelitian}

Semenjak tahun 1998, penebangan kayu oleh petani pada plot penelitian ini terjadi sangat intensif. Hampir seluruh pohon yang ada di dalam plot tersebut ditebangi sehingga hutan yang tadinya menutupi lahan sekarang sudah terbuka begitu saja. Daerah ini merupakan salah satu hutan hujan tropis basah yang terdapat di Sumatra Barat yang pada bagian kaki bukitnya hampir berubah akibat penebangan dan pembakaran hutan serta usaha pertanian seperti sawah, penanaman monokultur antara lain tanaman Pisang, Kelapa, Durian, Manggis, Anggrek serta spesies lainnya.

\section{Kondisi Iklim}

Rata-rata curah hujan bulanan tahun 1995 dan 2005 disajikan pada Gambar 1. Data suhu dan curah hujan diperoleh dari pengamatan langsung di lapangan pada tahun 2003 (Aflizar, 2003), untuk menentukan besarnya curah hujan dan temperatur pada tahun 2005 di lokasi plot penelitian ini dilakukan uji korelasi dengan data dari Badan meterologi dan Geofisika Padang. Dari data yang terdapat pada Gambar 1 dan 2 terlihat bahwa adanya fluktuasi rata-rata curah hujan dan suhu di kawasan Gunung Gadut selama 10 tahun.

Iklim pada kawasan ini menurut Koppen merupakan iklim tipe A. Iklim tipe A adalah 


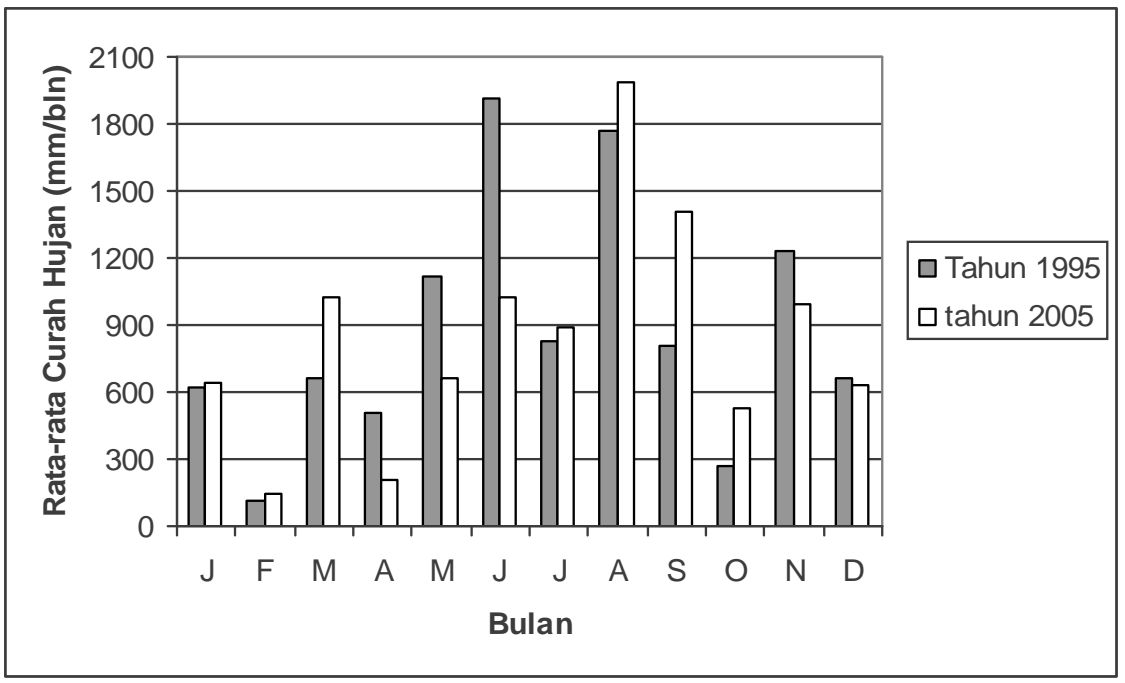

Gambar 1. Rata-rata Curah Hujan Bulanan Tahun 1995 dan 2005 di Gunuang Gaduik, Padang

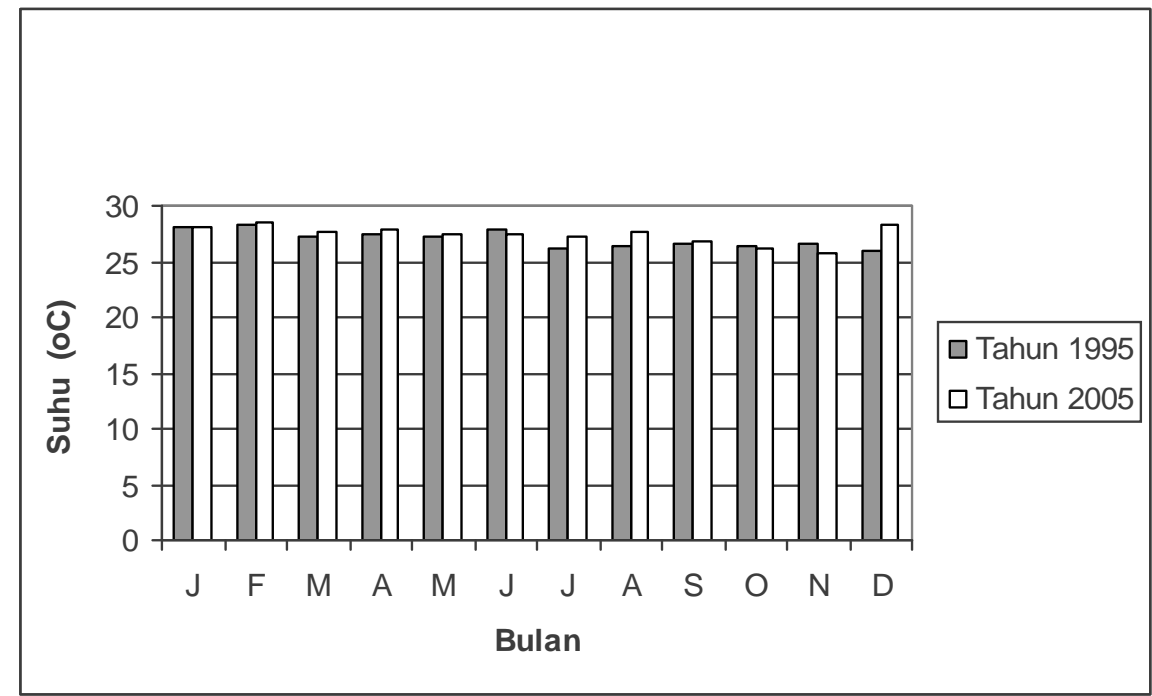

Gambar 2. Rata-rata Suhu Bulanan tahun 1995 dan 2005 di Gunung Gadut, Padang

iklim tropical rainy forest climate (Af) yang dipengaruhi oleh angin moonson (Tjasyono, 2004).

Pada tahun 1995 dan 2005 terlihat bahwa rata-rata curah hujan pada tahun 1995 sebesar $873,37 \mathrm{~mm} / \mathrm{bln}$ lebih tinggi bila dibandingkan dengan tahun 2005 yaitu sebesar 844,98 mm/bln. Adanya perbedaan ini diduga pengaruh dari penguapan dan arah angin. Sedangkan rata-rata suhu pada tahun
1995 sebesar $27^{\circ} \mathrm{C}$ lebih rendah bila dibandingkan dengan tahun 2005 yaitu sebesar $27,43^{\circ} \mathrm{C}$. Adanya peningkatan suhu pada tahun 2005 bila dibandingkan tahun 1995 diduga karena pengaruh dari perubahan iklim secara global yang disebabkan oleh efek rumah kaca. Menurut Tjasyono (2004)bahwa efek rumah kaca menyebabkan semakin menipisnya lapisan ozon di atmosfer karena adanya emisi karbon dioksida yang disebabkan oleh pencemaran 


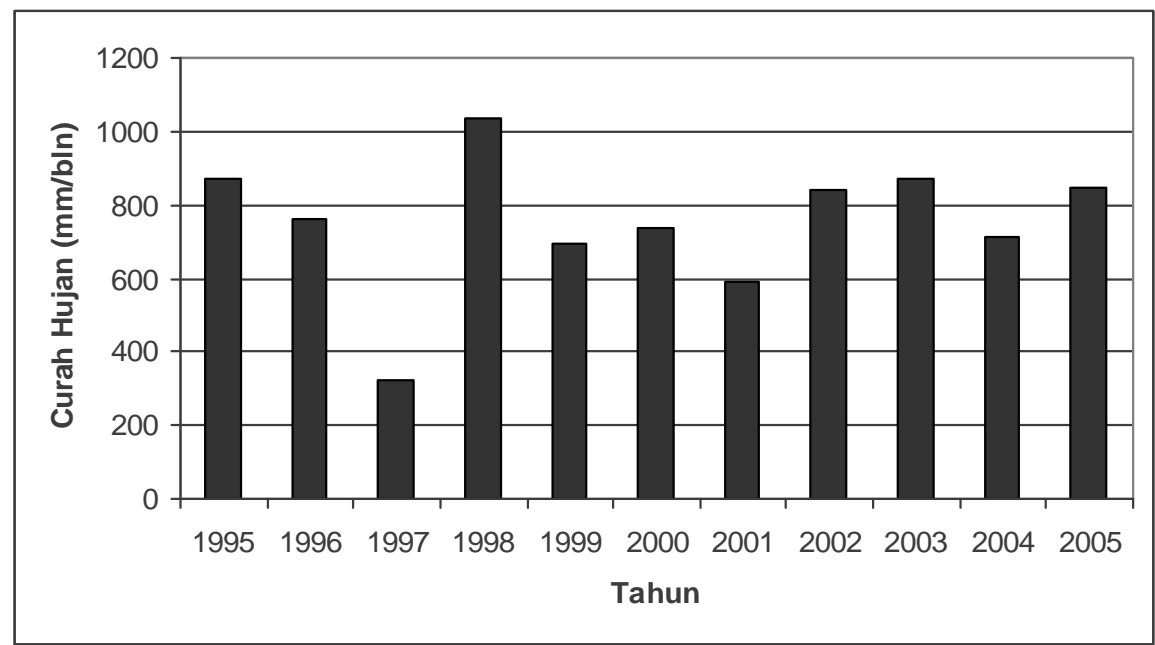

Gambar 3. Rata-rata Curah Hujan dari tahun 1995 sampai dengan 2005 di Plot Observasi Gajabuih, Gunung Gadut, Padang

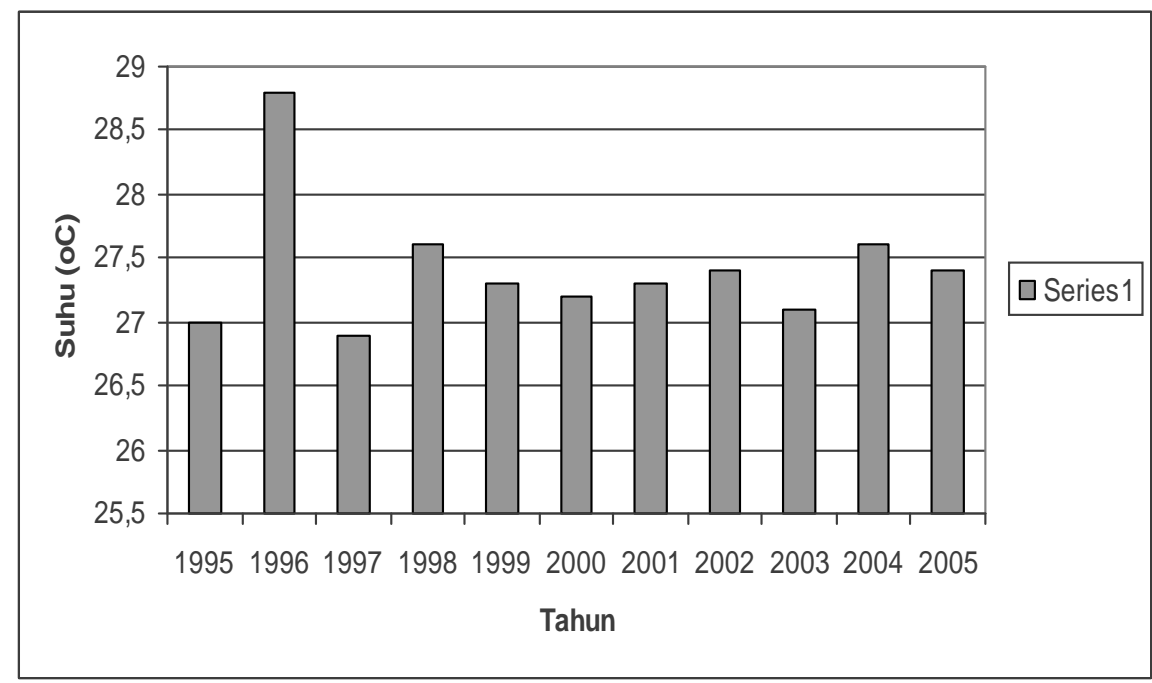

Gambar 4. Rata-rata Suhu dari tahun 1995 sampai dengan 2005 di Plot Gajabuih, Gunung Gadut, Padang

udara. Semakin menipisnya lapisan ozon menyebabkan radiasi matahari langsung menyinari bumi sehingga suhu dibumi terasa lebih panas (Tjasyono, 2004) .

Dilihat dari grafik suhu dan curah hujan dari tahun 1995 sampai dengan tahun 2005, jelas terlihat bahwa terjadi fluktuasi suhu dan curah hujan dari tahun ketahun. Hal ini diduga karena disebabkan terjadinya perubahan iklim yang disebabkan oleh berbagai faktor. Menurut Tjasyono (2004) bahwa faktor-faktor yang menyebabkan perubahan iklim tersebut antara lain oleh ulah manusia seperti urbanisasi, industrialisasi dan aktifitas alam seperti El Nino, letusan gunung api, dan lain sebagainya. 
Tabel 1. Nilai $\mathrm{pH}$ tanah pada setiap jenis famili tanah pada kedalaman 0-20 cm

Tahun 2005 di plot observasi Gajabuih, Gunung gadut

$$
\text { Jenis Famili Tanah } \quad \mathrm{pH} \mathrm{H}_{2} \mathrm{O}
$$

\begin{tabular}{ll}
\hline Oxic-dystroudept (eutric,aquic) & $5,10(\mathrm{~m})^{* *}$ \\
Oxic-dystroudept (xanthic) & $5,22(\mathrm{~m})$ \\
Oxic-Typic-dystroudept (xanthic) & $5,13(\mathrm{~m})$
\end{tabular}

${ }^{* *}$ Sumber : team 4 Architecs \& Consulting Engineers bekerjasama dengan Fakultas Pertanian Universitas Andalas (1981)

Keterangan : $\mathrm{m}=$ masam

Reaksi Tanah

Reaksi tanah menyatakan reaksi asambasa dalam tanah. Hasil analisis $\mathrm{pH}$ tanah untuk plot penelitian ini disajikan pada Tabel 2. Dari Tabel 2 terlihat bahwa nilai $\mathrm{pH}$ tanah pada setiap famili tanah memperlihatkan perbedaan yang tidak nyata.

Hasil analisis sifat kemasaman tanah (pH) yang diteliti pada tahun 2005 pada setiap jenis famili tanah disajikan pada Tabel 1 pada kedalaman $0-20 \mathrm{~cm}$ secara statistik dan

kriteria tidak memperlihatkan perbedaan yang nyata. Pada Tabel 1 dapat ditemukan bahwa nilai $\mathrm{pH}$ tanah pada 3 jenis famili tanah berkisar 5,1-5,2 pada kedalaman 0-20 $\mathrm{cm}$. Setelah diteliti berdasarkan kriteria tanah, maka terlihat pada kawasan ini semuanya termasuk dalam kriteria masam. Tanah-tanah yang berada pada kawasan iklim basah umumnya bereaksi masam dengan kisaran $\mathrm{pH}$ antara 4,5-5,5. Tingginya curah hujan pada kawasan ini menyebabkan kation-kation basa mudah tercuci kelapisan bawah (Tan, 1991). Lebih lanjut Rosmarkam dan Yuwono (2002) menyatakan bahwa di daerah lembab meskipun tanahnya terbentuk dari batuan kapur namun seringkali lapisan atasnya bereaksi masam yang disebabkan hilangnya kation-kation basa akibat pencucian yang berlebihan.

Proses dekomposisi yang relatif cepat di kawasan ini yang dapat di lihat dari relatif rendahnya nisbah $\mathrm{C} / \mathrm{N}$ diduga juga mampu menyebabkan reaksi masam pada tanah.
Hakim et al, (1986) menyatakan bahwa hasil dekomposisi bahan organik diantaranya seperti $\mathrm{H}_{2} \mathrm{CO}_{3}$ yang dapat melarutkan basa-basa dari batuan, dengan demikian basa-basa akan cepat hilang atau diserap tanaman. Tan, (1991) menyatakan bahwa asam-asam organik dan anorganik, yang dihasilkan oleh penguraian bahan organik tanah, merupakan konstituen tanah yang umum yang dapat mempengaruhi kemasaman tanah. Respirasi akar tanaman menghasilkan $\mathrm{CO}_{2}$ yang akan membentuk $\mathrm{H}_{2} \mathrm{CO}_{3}$ dalam air ikut membantu sebagai pelarut dan pengurai di dalam tanah. Air merupakan sumber lain dari sejumlah kecil ion $\mathrm{H}^{+}$. Suatu bagian yang besar dari ion $\mathrm{H}^{+}$yang ada dalam tanah akan dijerap oleh kompleks lempung sebagai ion-ion $\mathrm{H}^{+}$yang dapat dipertukarkan. Ion-ion $\mathrm{H}^{+}$tertukarkan tersebut berdisosiasi menjadi ion-ion $\mathrm{H}^{+}$bebas. Kemasaman aktif diukur dan dinyatakan sebagai $\mathrm{pH}$ tanah.

Karakteristik Hara Tanah Pada 3 Posisi Topografi Tahun 1995 dan 2005 pada Plot Observasi Gajabuih, Gunung Gadut

\section{Kandungan P tersedia Tanah}

Hasil analisis $\mathrm{P}$ tersedia tanah pada 3 jenis famili tanah untuk plot penelitian ini disajikan pada Tabel 3.

Kandungan $\mathrm{P}$ tersedia tanah pada kedalaman 0-20 cm antar setiap jenis famili tanah tahun 2005 secara statistik tidak memperlihatkan perbedaan yang nyata, demikian juga kandungan $\mathrm{P}$ tersedia untuk setiap jenis famili tanah termasuk pada kriteria 
Tabel 2. Kandungan P tersedia tanah Tahun 1995 dan 2005 pada 3 jenis famili Tanah pada kedalaman tanah $0-20 \mathrm{~cm}$.

\begin{tabular}{lcc}
\hline \multicolumn{1}{c}{ Jenis Famili Tanah } & \multicolumn{2}{c}{ P-tersedia (ppm) } \\
\cline { 2 - 3 } & $5,84(\mathrm{r})^{* *}$ & 2005 \\
\hline Oxic-dystroudept (eutric,aquic) & $6,01(\mathrm{r})$ & $22,63(\mathrm{~s})$ \\
Oxic-dystroudept (xanthic) & $5,79(\mathrm{r})$ & $25,50(\mathrm{~s})$ \\
Oxic-Typic-dystroudept (xanthic) &
\end{tabular}

** Sumber : team 4 Architecs \& Consulting Engineers bekerjasama dengan Fakultas Pertanian Universitas Andalas (1981)

Keterangan : $r=$ rendah, $s=$ sedang

sedang. Kandungan $\mathrm{P}$ tersedia pada kedalaman 0-20 cm antar setiap jenis famili tanah tahun 1995 secara statistik juga tidak memperlihatkan perbedaan yang nyata, demikian juga kandungan $\mathrm{P}$ tersedia untuk setiap jenis famili tanah termasuk pada kriteria rendah. Namun jika dibandingkan status kandungan $\mathrm{P}$ tersedia tanah tahun 2005 dengan tahun 1995, kandungan $\mathrm{P}$ tersedia memperlihatkan perbedaan yang signifikan. Secara kriteria $\mathrm{P}$ tersedia tahun 2005 berada pada kriteria sedang. Peningkatan $\mathrm{P}$ tersedia terlihat tinggi. Peningkatan $\mathrm{P}$ tersedia sebesar $320 \%$.

Lebih tingginya kandungan $\mathrm{P}$ tersedia pada tahun 2005 diduga disebabkan oleh bahan organik yang disumbangkan melalui sarasah-sarasah perdu pada tahun itu serta didukung oleh banyaknya pohon yang tumbang yang merupakan sebagai sumber penambah bahan organik. Hasil dari dekomposisi bahan organik tersebut akan menyumbangkan $\mathrm{P}$ tersedia di dalam tanah dan melarutkan sumber-sumber mineral yang kemungkinan ada didalam tanah.

Pada Tabel 2, terlihat bahwa kandungan $\mathrm{P}$ tersedia tertinggi adalah $\quad 25,94 \mathrm{ppm}$ ditemukan pada jenis famili tanah oxicdystroudept (eutric, aquic) pada tahun 2005. Hal ini diduga karena jenis famili tanah ini relatif lebih subur (eutric) daripada dua famili tanah lainnya serta kelembaban yang lebih banyak (aquic) dari jenis famili tanah lainnya. Hal ini juga didukung oleh tinggginya populasi tumbuhan yang baru tumbuh di daerah ini. Dengan memiliki tanah yang relatif lebih subur dan kelembaban lebih banyak menyebabkan daerah ini memiliki jumlah populasi tanaman lebih banyak dengan jenisnya lebih sedikit. Hal ini sesuai dengan apa yang ada di lapangan. Hal ini sejalan dengan apa yang ditemukan oleh Kubota (1999) yang menyatakan bahwa pada daerahdaerah yang tanahnya relatif subur cenderung memiliki populasi yang tinggi dengan jenis spesies yang sedikit. Pada daerah ini sarasah yang dihasilkan lebih banyak dari tempat yang lainnya. Menumpuknya sarasah dan tingginya kandungan bahan organik di lapisan atas sangat mendukung ketersediaan $\mathrm{P}$ baik $\mathrm{P}$ organik maupun anorganik di dalam tanah. Shanchez (1992) didalam tulisannya menyatakan bahwa, seorang peneliti di Afrika menemukan bahwa Fosfor organik menjadi sumber utama $\mathrm{P}$ bagi tanaman, dan Fosfor organik merupakan penyebab terdapatnya 20$50 \%$ seluruh $\mathrm{P}$ di tanah atas. Tinggi populasi dan jenis spesies pada posisi ini juga mempengaruhi ketersediaan $\mathrm{P}$ di dalam tanah. Fox et al (1974 cit Shanchez, 1992) menyatakan $\mathrm{P}$ tersedia di dalam tanah sangat berhubungan dengan pertumbuhan tanaman dan hal ini berbeda menurut spesies. Berbedanya kebutuhan $\mathrm{P}$ suatu tanaman akan menyebabkan berbeda pula kandungan hara $\mathrm{P}$ di dalam tubuh tanaman tersebut dan biomassa yang akan dihasilkan. 
Tabel 3. Kandungan Ca-dd tanah Tahun 1995 dan 2005 pada 3 jenis famili tanah pada kedalaman tanah $0-20 \mathrm{~cm}$

\begin{tabular}{lll}
\hline \multirow{2}{*}{ Jenis Famili Tanah } & \multicolumn{2}{c}{ Ca-dd (me/100g tnh) } \\
\cline { 2 - 3 } & \multicolumn{1}{c}{1995} & 2005 \\
\hline Oxic-dystroudept (eutric,aquic) & $9,46(\mathrm{t})^{* *}$ & $2,38(\mathrm{r})$ \\
Oxic-dystroudept (xanthic) & $9,10(\mathrm{t})$ & $2,29(\mathrm{r})$ \\
Oxic-Typic-dystroudept (xanthic) & $8,50(\mathrm{t})$ & $2,03(\mathrm{r})$
\end{tabular}

**:Sumber : team 4 Architecs \& Consulting Engineers bekerjasama dengan Fakultas Pertanian Universitas Andalas (1981)

Keterangan : $\mathrm{r}=$ rendah, $\mathrm{s}=$ sedang, $\mathrm{t}=$ tinggi

Kandungan Ca-dd Tanah

Hasil analisis Ca-dd tanah pada tahun 1995 dan 2005 di plot Observasi Gajabuih pada 3 jenis famili tanah pada kedalaman 0-20 cm disajikan pada Tabel 3. Pada tabel tersebut akan terlihat perbedaan Ca-dd tanah yang terjadi antara tahun 1995 dan 2005.

Kandungan Ca-dd pada kedalaman 0$20 \mathrm{~cm}$ tahun 2005 pada tiap famili tanah secara statistik dan kriteria tidak memperlihatkan perbedaan yang nyata, secara kriteria pada lapisan ini Ca-dd berada dalam kriteria rendah. Pada kedalaman yang sama $(0-20 \mathrm{~cm})$ kandungan $\mathrm{Ca}$-dd pada tiap jenis famili tanah tahun 1995 secara statistik dan kriteria tidak memperlihatkan perbedaan yang nyata, penilaian secara kriteria pada lapisan ini Ca-dd berada dalam kriteria tinggi. Jadi pada kedalaman tanah 0-20 cm tersebut, kandungan Ca-dd menurun $313 \%$ dari tahun 1995 ketahun 2005.

Jika dibandingkan kandungan Ca-dd tahun 1995 dan 2005, terlihat bahwa kandungan $\mathrm{Ca}$ menurun dengan tajam. Penurunan ini disebabkan karena terjadinya perubahan vegetasi dan hilangnya hara melalui litterfall juga berkurang secara signifikan. Perubahan vegetasi disebabkan oleh penebangan yang dilakukan pada tahun 19982000 yang menyebabkan hutan menjadi gundul sehingga terjadi erosi/penghanyutan basa-basa oleh air hujan, apalagi pada daerah penelitian ini $93,4 \%$ termasuk topografi yang curam dan $6,76 \%$ termasuk topografi yang sangat curam (lampiran 2) dan daerah ini memiliki curah hujan yang tinggi. Menurut Rusman, (1999) pada lereng yang lebih miring dan panjang, partikel halus terangkut lebih jauh lagi. Dengan makin besarnya volume aliran permukaan dan dengan kecepatan yang besar akan mendorong pengangkutan partikel yang halus lebih jauh lagi, sedangkan dengan adanya vegetasi diatas permukaan lahan akan menghalangi pengangkutan partikel tanah lebih jauh lagi. Hal yang terjadi juga didukung oleh lebih tingginya kandungan Ca-dd tahun 1995 dan 2005 pada jenis famili tanah Oxicdystroudept (eutric, aquic) karena topografinya yang agak datar sehingga erosi tidak terlalu besar.

Penurunan Ca-dd tanah juga disebabkan oleh sifat dari ion $\mathrm{Ca}$ tersebut. Pada koloid tanah ion divalen diikat lebih kuat daripada ion-ion monovalen. Ion $\mathrm{Ca}$ merupakan ion divalen. Namun begitu ion divalen mempunyai daya terobos yang rendah dan ion monovalen mempunyai daya terobos yang tinggi sehingga ion divalen yang telah berada pada koloid tanah digantikan oleh ion monovalen. Ion divalen yang telah berada pada larutan tanah akan terbawa oleh erosi dan tercuci (Tan, 1991).

Rendahnya Ca-dd pada tanah sebagaimana yang diungkapkan oleh Aflizar (2003) disebabkan kandungan Ca yang lebih tinggi pada daun dari pada di dalam tanah. Hal ini didukung oleh pendapat Rosmarkam dan Yuwono (2002) yang menyatakan bahwa $\mathrm{Ca}$ terutama terdapat dalam daun dan sering mengendap berupa kristal kalsium oksalat. 
Tabel 4. Kandungan Mg-dd tanah Tahun 1995 dan 2005 pada 3 jenis famili tanah pada kedalaman tanah $0-20 \mathrm{~cm}$

\begin{tabular}{llc}
\hline \multicolumn{1}{c}{ Jenis Famili Tanah } & \multicolumn{2}{c}{ Mg-dd (me/100g tnh) } \\
\cline { 2 - 3 } & \multicolumn{1}{c}{1995} & 2005 \\
\hline Oxic-dystroudept (eutric,aquic) & $0,57(\mathrm{r})^{* *}$ & $0,40(\mathrm{sr})$ \\
Oxic-dystroudept (xanthic) & $0,40(\mathrm{r})$ & $0,33(\mathrm{sr})$ \\
Oxic-Typic-dystroudept (xanthic) & $0,41(\mathrm{r})$ & $0,32(\mathrm{sr})$
\end{tabular}

**:Sumber : team 4 Architecs \& Consulting Engineers bekerjasama dengan Fakultas Pertanian Universitas Andalas (1981)

Keterangan $: \mathrm{r}=$ rendah, $\mathrm{sr}=$ sangat rendah

Kandungan Mg-dd Tanah

Hasil analisis Mg-dd tanah pada tahun 1995 dan 2005 di plot observasi Gajabuih pada 3 famili tanah disajikan pada Tabel 4.

Kandungan Mg-dd pada tahun 2005 secara statistik dan kriteria tidak memperlihatkan perbedaan yang nyata, secara kriteria pada lapisan ini Mg-dd berada dalam kriteria sangat rendah.

Sedangkan pada tahun 1995 kandungan Mg-dd pada kedalaman 0-20 $\mathrm{cm}$ pada tiap jenis famili tanah tahun 1995 tidak memperlihatkan perbedaan nyata, baik secara kriteria maupun statistik, secara kriteria pada lapisan ini Mg-dd berada dalam kriteria rendah. Jadi terjadi perubahan kriteria, yaitu kriteria rendah pada tahun 1995 dan menurun menjadi kriteria sangat rendah pada tahun 2005. Penurunan tersebut sebanyak $31,4 \% \%$ selama 10 tahun.

Suatu hal yang sangat menarik pada kawasan ini air hujan yang turun di sini didominasi oleh $\mathrm{Ca}^{+2}$ dan $\mathrm{Mg}^{+2}$, air hujan yang jatuh ke tanah yang membawa lebih banyak kandungan $\mathrm{Ca}$ dan $\mathrm{Mg}$ tadi mengalir ke bawah. Udara di sekitar Hulu Gadut mengandung partikel-partikel debu yang mengandung senyawa $\mathrm{CaO}$ dan $\mathrm{MgO}$ yang merupakan senyawa penyusun semen PT. Semen Padang (Rasyidin dan Wakatsuki, 1994; Ganidan Munir 1995 cit Yuafriza 1999) menyatakan bahwa kendatipun begitu kandungan Mg-dd antara tahun 1995 dan tahun 2005 sedikit memperlihatkan perbedaan yang nyata. Hal ini diduga karena sifat $\mathrm{Mg}$ yang memiliki mobilitas yang tinggi. Curah hujan yang tinggi pada kawasan ini didukung oleh keadaan topografi yang curam dan landai mengakibatkan terjadinya proses pencucian dan erosi. Hal ini menyebabkan $\mathrm{Mg}$ hanyut ke bawah (Hardjowigeno, 2003). Hal yang terjadi juga didukung oleh lebih tingginya kandungan Mg-dd tahun 1995 dan 2005 pada jenis famili tanah Oxic-dystroudept (eutric, aquic) karena topografinya yang agak datar sehingga erosi tidak terlalu besar.

Reaksi tanah pada kawasan ini termasuk pada kriteria masam (Tabel 2). Suatu peningkatan $\mathrm{pH}$ dikaitkan dengan suatu peningkatan jumlah Kalsium dan Magnesium didalam larutan tanah, sebab mereka biasanya merupakan basa dapat ditukar yang dominan (Foth, 1998). Karena pada tanah masam $\mathrm{H}^{+}$ mendominasi pada tanah. Ion hidrogen dijerap lebih kuat daripada ion-ion monovalen atau ion-ion divalen dan mempunyai daya tembus yang sangat tinggi. Sehinggga ion $\mathrm{Mg}^{+2}$ yang mempunyai daya tembus yang rendah digantikan oleh ion hidrogen didalam koloid tanah. Ion $\mathrm{Mg}^{+2}$ yang berada pada larutan tanah akan mudah terbawa erosi dan tercuci (Tan, 1991).

Kandungan K-dd Tanah

Hasil analisis K-dd tanah pada tahun 1995 dan 2005 di plot observasi Gajabuih pada 3 famili tanah disajikan pada tabel 5 .

Kandungan K-dd pada kedalaman 0-20 cm pada tiap jenis famili tanah tahun 1995 dan tahun 2005 secara satatistik dan kriteria tidak 
Tabel 5. Kandungan K-dd tanah tahun 1995 dan 2005 pada 3 jenis Famili Tanah pada kedalaman tanah $0-20 \mathrm{~cm}$

\begin{tabular}{llc}
\hline \multicolumn{1}{c}{ Jenis Famili Tanah } & \multicolumn{2}{c}{ K-dd (me/100g tnh) } \\
\cline { 2 - 3 } & \multicolumn{1}{c}{1995} & 005 \\
\hline Oxic-dystroudept (eutric,aquic) & $0,194(\mathrm{r})^{* *}$ & $0,30(\mathrm{r})$ \\
Oxic-dystroudept (xanthic) & $0,197(\mathrm{r})$ & $0,22(\mathrm{r})$ \\
Oxic-Typic-dystroudept (xanthic) & $0,222(\mathrm{r})$ & $0,20(\mathrm{r})$
\end{tabular}

** Sumber : team 4 Architecs \& Consulting Engineers bekerjasama dengan Fakultas Pertanian Universitas Andalas (1981)

Keterangan : $r=$ rendah, na $=$ tidak terukur

memperlihatkan perbedaan yang nyata. Secara kriteria pada kedalaman 0-20 cm K-dd berada dalam kriteria rendah, baik pada tahun 1995 maupun pada tahun 2005.

Sedikitnya kandungan K-dd didalam tanah manurut Hardjowigeno (1987) disebabkann tumbuhan yang cenderung mengambil K-dd dalam jumlah yang lebih banyak dari yang dibutuhkan tetapi tidak diiringi dengan peningkatan produksi.Apalagi pada daerah penelitian ini telah terjadi penebangan hutan dan erosi. Erosi terjadi karena plot penelitian ini mempunyai topografi yang curam dan curah hujan yang tinggi. Erosi dapat mengakibatkan kehilangan beberapa unsur hara termasuk unsur $\mathrm{K}$. Hal ini didukung oleh lebih tingginya kandungan $\mathrm{K}$ dd tahun 2005 pada jenis famili tanah Oxicdystroudept (eutric, aquic) karena topografinya yang agak datar sehingga erosi tidak terlalu besar.

Sedikit meningkatnya kandungan K-dd didalam tanah pada tahun 1995 juga diduga oleh karena pada tanah banyak terdapat sisasisa dari penebangan hutan tahun 2000 berupa kayu-kayu besar yang melapuk dan menambah kandungan K-dd di tanah. Apalagi nisbah $\mathrm{C} / \mathrm{N}$ pada daerah ini pada umumnya pada kriteria sedang sehingga ketersediaan K-dd sedikit lebih tinggi jika dibandingkan pada tahun 1995 karena dekomposisi bahan organik pada kawasan ini belum lanjut. Hakim et al (1986) juga menyatakan rendahnya K-dd dalam tanah juga karena adanya akumulasi oleh mikroorganisme sebagai sumber energi dalam melakukan perombakan dimana mikroorganisme menggunakan $\mathrm{K}$ sebagai pembentuk sel-sel baru. Foth (1998) juga menyatakan bahwa Kalium tersedia rendah cenderung terjadi pada tanah masam.

Namun pada tabel 6, pada jenis famili tanah oxic-dystroudept (eutric, aquic) pada kedalaman 0-20 cm tahun 2005 kandungan Kdd lebih tinggi dari jenis famili tanah lainnya, hal ini disebabkan oleh keadaan topografi yang relatif datar sedangkan pada daerah yang lain curam. Bila dibandingkan pada tahun 1995 pada jenis famili tanah oxic-dystroudept (eutric, aquic) kandungan K-dd tidak pada posisi tertinggi, hal ini disebabkan oleh vegetasi pada daerah ini yang pada tahun 1995 masih sebagai hutan hujan tropis, sehingga penghanyutan basa-basa yang terjadi tidak terlalu besar karena ada akar-akar tanaman sebagai penahan. Dengan adanya vegetasi diatas permukaan lahan akan menghalangi pengangkutan partikel tanah lebih jauh lagi pada permukaan tanah yang curam dan landai (Rusman, 1999).

Kandungan Na-dd Tanah

Hasil analisis Na-dd tanah di plot observasi Gajabuih pada 3 jenis famili tanah disajikan pada Tabel 6.

Kandungan Na-dd pada kedalaman 0-20 $\mathrm{cm}$ tahun 2005 secara statistik tidak memperlihatkan perbedaan yang nyata. Tapi 
Tabel 6. Kandungan Na-dd tanah Tahun 1995 dan 2005 pada 3 jenis famili tanah pada kedalaman tanah $0-20 \mathrm{~cm}$

\begin{tabular}{lll}
\hline \multicolumn{1}{c}{ Jenis Famili Tanah } & \multicolumn{2}{c}{ Na-dd (me/100g tnh) } \\
\cline { 2 - 3 } & \multicolumn{1}{c}{1995} & 2005 \\
\hline Oxic-dystroudept (eutric,aquic) & $0,094(\mathrm{sr})^{* *}$ & $0,47(\mathrm{~s})$ \\
Oxic-dystroudept (xanthic) & $0,092(\mathrm{sr})$ & $0,33(\mathrm{r})$ \\
Oxic-Typic-dystroudept xanthic) & $0,100(\mathrm{sr})$ & $0,34(\mathrm{r})$
\end{tabular}

** Sumber : team 4 Architecs \& Consulting Engineers bekerjasama dengan Fakultas Pertanian Universitas Andalas (1981)

Keterangan : $\mathrm{sr}=$ sangat rendah, $\mathrm{r}=$ rendah, $\mathrm{s}=$ sedang

secara kriteria memperlihatkan perbedaan yang nyata.

Dari data yang disajikan pada Tabel 6 pada jenis famili tanah Oxic-dystroudept (eutric, aquic) kriteria Na-dd tanah adalah sedang, sedangkan jenis famili tanah Oxicdystroudept (xanthic) dan Oxic-Typicdystroudept (xanthic) kriteria Na-dd tanah adalah rendah. Sedangkan kandungan Na-dd pada kedalaman 0-20 cm pada setiap jenis famili tanah tahun 1995 tidak memperlihatkan perbedaan yang nyata secara statistik dan kriteria, secara kriteria pada lapisan iniNa-dd berada dalam kriteria sangat rendah. Hal tersebut juga berarti kandungan Na-dd pada tahun 2005 mengalami peningkatan $300 \%$ dari tahun 1995.

Terjadinya peningkatan kandungan Na-dd pada tahun 2005 diduga karena adanya pengaruh curah hujan yang menyumbangkan ion-ion Na yang cukup besar kedalam tanah pada kawasan ini. Hal ini disebabkan karena adanya pengaruh air laut yang mengandung ion-ion $\mathrm{Na}$ dan dibawa oleh angin kedaratan dan kemudian diturunkan melalui hujan (Yuafriza, 1999).

Dilihat dari tabel 6 diatas bahwa kandungan Na-dd tertinggi terdapat pada tahun 2005 pada jenis famili tanah oxicdystroudept (eutric, aquic) yaitu $\quad 0,470$ $\mathrm{me} / 100 \mathrm{~g}$ tanah. Hal ini disebabkan oleh tanah yang banyak mengandung air (aquic), serta didukung oleh bentuk permukaan yang agak datar (sedikit cekung) bila dibandingakan dengan 2 jenis famili tanah lainnya yang mempunyai bentuk permukaan yang curam. Pada jenis famili tanah oxic-dystroudept (eutric, aquic) kandungan $\mathrm{Na}$ tentu lebih banyak tersimpan oleh tanah karena sifat yang dimiliki tanahnya dan bentuk permukaannya yang relatif datar. Sedangkan pada jenis famili tanah yang lain bentuk permukaannya curam sehingga memudahkan terjadinya erosi.

\section{Nisbah $\mathrm{C} / \mathrm{N}$}

Hasil analisis $\mathrm{C} / \mathrm{N}$ tanah pada tahun 1995 dan tahun 2005 di daerah plot penelitian Bukit Gajabuih Gunung Gadut Padang yang terdiri atas 3 jenis famili tanah pada kedalaman tanah 0-20 cm disajikan pada Tabel 7.

Nisbah C/N pada kedalaman 0-20 cm pada tiap famili tanah mengalami penurunan. Pada tanah Oxic-dystroudept (eutric, aquic) menurun sebesar $43,6 \%$ selama 10 tahun, pada tanah Oxic-dystroudept (xanthic) menurun sebesar $7,4 \%$ selama 10 tahun, pada tanah Oxic-Typicdystroudept (xanthic) menurun sebesar 36,2\%. Penurunan $\mathrm{C} / \mathrm{N}$ pada plot penelitian sebesar $29,06 \%$.

Nisbah C/N pada tahun 2005 pada kedalaman $0-20 \mathrm{~cm}$ secara statistik tidak memperlihatkan perbedaan yang nyata namun mempunyai kriteria yang berbeda yaitu pada jenis famili tanah oxic-dystroudept (eutric, aquic) berada dalam kriteria rendah sedangkan pada jenis famili tanah oxic-typic-dystroudept (xanthic) dan oxic-dystroudept (xanthic) berada dalam kriteria sedang. Nisbah $\mathrm{C} / \mathrm{N}$ 
Tabel 7. Nisbah C/N Tanah Tahun 1995 dan 2005 pada 3 jenis famili tanah pada kedalaman tanah $0-20 \mathrm{~cm}$

\begin{tabular}{lccc}
\hline \multicolumn{1}{c}{ Jenis famili tanah } & \multicolumn{2}{c}{ C/N } & $\begin{array}{c}\text { \% perubahan } \\
\text { tiap famili } \\
\text { tanah }\end{array}$ \\
\cline { 2 - 3 } & 1995 & 2005 & $43,6 \%$ \\
\hline Oxic-dystroudept (eutric,aquic) & $13,24(\mathrm{~s})^{* * *}$ & $9,220(\mathrm{r})$ & $7,4 \%$ \\
Oxic-dystroudept (xanthic) & $14,28(\mathrm{~s})$ & $13,29(\mathrm{~s})$ & $36,2 \%$ \\
Oxic-Typic-dystroudept (xanthic) & $17,38(\mathrm{~s})$ & $12,76(\mathrm{~s})$ & \multicolumn{3}{c}{ Menurun $29,06 \%$} \\
\hline Selisih keseluruhan & \multicolumn{3}{c}{. } \\
\hline
\end{tabular}

** Sumber : team 4 Architecs \& Consulting Engineers bekerjasama dengan Fakultas Pertanian Universitas Andalas (1981)

Keterangan : $\mathrm{r}=$ rendah, $\mathrm{s}=$ sedang

pada kedalaman yang sama (0-20) $\mathrm{cm}$ tahun 1995 secara statistik dan kriteria tidak memperlihatkan perbedaan yang nyata, secara kriteria lapisan ini berada dalam kriteria sedang.

Nisbah $\mathrm{C} / \mathrm{N}$ merupakan suatu peubah untuk mengetahui tingkat kecepatan dekomposisi. Semakin tinggi nisbah $\mathrm{C} / \mathrm{N}$ menandakan bahwa dekomposisi bahan organik pada kawasan tersebut belum lanjut dan $\mathrm{C} / \mathrm{N}$ yang rendah menunjukkan dekomposisi bahan organiknya sudah lanjut. Rendahnya nisbah $\mathrm{C} / \mathrm{N}$ menandakan rendahnya C-Organik sementara kandungan N-nya tinggi.Menurut Konova (1996 cit Aflizar, 2003) bahwa sumber C-Organik adalah dari $\mathrm{CO}_{2}$ dialam yang berasal dari dekomposisi bahan organik berupa sisa tanaman dan hewan dan dari respirasi invetebrata, bakteri dan fungi. Kemudian bahan organik didekomposisikan kembali sehingga akan membebaskan sejumlah karbon. Sedangkan senyawa yang mengandung nitrogen sebagai hasil dekomposisi bahan organik adalah amonium, nitrit dan nitrat serta nitrogen.

Jika dilihat dari tabel 8 kandungan nisbah $\mathrm{C} / \mathrm{N}$ pada umumnya dalam kriteria sedang, baik pada tahun 1995 maupun 2005 . Pada tahun 1995 banyak terdapat sarasahsarasah yang belum terlapuk sempurna karena cahaya matahari tidak langsung kepermukaan tanah. Sedangkan pada tahun 2005 disebabkan masih tertumpuknya sisa-sisa penebangan hutan pada tahun 2002 pada bagian permukaan dan sisa-sisa tumbuhan lainnya yang telah mati pada lapisan atas. Sebagaimana yang ditemukan dilapangan saat penelitian bahwa masih banyak sisa-sisa penebangan yang masih setengah melapuk. Hal tersebut karena pohon yang ditebang berukuran besar sehingga sisa-sisa penebangan hutan tersebut belum terdekomposisi dengan sempurna.

Jika dilihat dari tabel 7 tahun 2005, maka pada jenis famili tanah oxic-dystroudept (eutric, aquic) mengandung nisbah $\mathrm{C} / \mathrm{N}$ yang lebih rendah dari jenis famili tanah lainnya. Hal ini disebabkan oleh keadaan tanahnya yang lebih lembab sehingga proses dekomposisi lebih cepat, sebagaimana yang dinyatakan oleh Soedarsono (1981) bahwa cepatnya proses dekomposisi disebabkan oleh kelembaban yang tinggi sehingga jamur lebih aktif merombak bahan yang akan didekomposisikan. Adanya fluktuasi suhu dan curah hujan disetiap tahun sangat mempengaruhi proses dekomposaisi dan nisbah C/N. Curah hujan yang besar dan suhu yang tinggi dapat menghasilkan kelembaban yang ideal untuk menunjang meningkatnya laju aktifitas mikroorganisme (Winarto, 2003).

Nisbah C/N pada tahun 2005 menurun bila dibandingkan dengan nisbah $\mathrm{C} / \mathrm{N}$ pada tahun 1995. Terjadinya penurunan nisbah $\mathrm{C} / \mathrm{N}$ 
menandakan proses dekomposisi sudah melapuk lanjut. Kondisi ini diduga karena lebih banyaknya bahan organik yang didekomposisikan pada tahun 2005 yang didukung oleh lebih tingginya suhu. Menurut Hakim et al (1986) bahwa menurunnya nisbah $\mathrm{C} / \mathrm{N}$ berkolerasi dengan iklim seperti suhu dan curah hujan. Hardjowigeno (1987) menyatakan bahwa semakin banyak bahan organik yang dimanfaatkan maka penurunan nisbah $\mathrm{C} / \mathrm{N}$ juga semakin cepat.

Cadangan $\mathrm{P}$ tersedia tanah pada setiap famili tanah mengalami peningkatan. Pada tanah Oxic-dystroudept (eutric, aquic) $\mathrm{P}$ tersedia meningkat sebesar $336 \%$ selama 10 tahun, pada tanah Oxic-dystroudept (xanthic) $\mathrm{P}$ tersedia meningkat sebesar $292 \%$ selama 10 tahun, pada tanah Oxic-Typic-dystroudept (xanthic) P tersedia meningkat sebesar 393\% selama 10 tahun. Cadangan $\mathrm{P}$ tersedia pada tahun 2005 lebih tinggi bila dibandingkan tahun 1995. Jadi terjadi peningkatan cadangan $\mathrm{P}$ tersedia selama 10 tahun. Peningkatan cadangan $\mathrm{P}$ tersedia tanah terjadi sebesar $340 \%$.

Ketersediaan cadangan $\mathrm{P}$ tersedia tanah pada tahun 2005 yang lebih besar bila dibandingkan dengan tahun 1995 diduga disebabkan oleh banyaknya pohon-pohon yang tumbang pada tahun 2000 dan 2002 akibat penebangan liar yang dilakukan oleh warga sekitar sehingga banyak menyumbangkan cadangan $\quad P$ tersedia dalam tanah. Hal ini juga didukung oleh banyaknya sarasahsarasah perdu yang jatuh pada tahun 2005

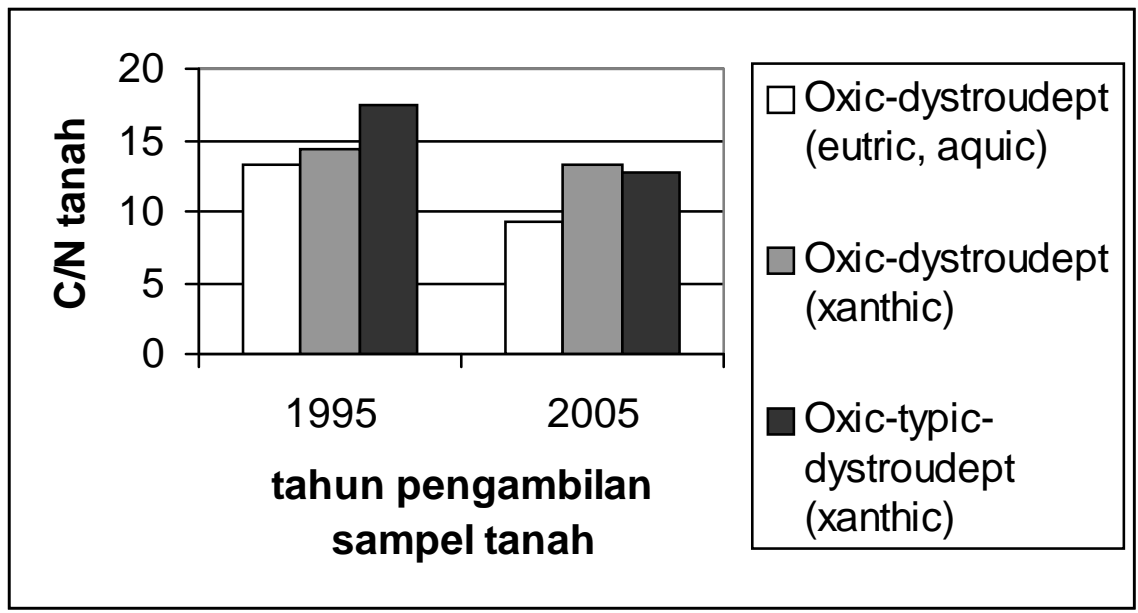

Gambar 5. Perubahan C/N tanah Tahun 1995 dan 2005 pada kedalaman tanah 0-20 cm di Plot Observasi Gajabuih, Gunung Gadut, Padang

Tabel 8. Perubahan P tersedia tanah Tahun 1995 dan 2005 pada kedalaman tanah 0-20 cm di plot observasi Gajabuih, Gunung Gadut

\begin{tabular}{|c|c|c|c|}
\hline \multirow[t]{2}{*}{ Jenis Famili Tanah } & \multicolumn{2}{|c|}{$\begin{array}{l}\text { P-tersedia } \\
(\mathrm{kg} / \mathrm{ha})\end{array}$} & \multirow[t]{2}{*}{$\begin{array}{l}\text { \% Perubahan tiap famili } \\
\text { tanah }\end{array}$} \\
\hline & 1995 & 2005 & \\
\hline Oxic-dystroudept (eutric,aquic) & 5,68 & 24,77 & $336 \%$ \\
\hline Oxic-dystroudept (xanthic) & 5,97 & 23,39 & $292 \%$ \\
\hline Oxic-Typic-dystroudept (xanthic) & 5,01 & 24,70 & $393 \%$ \\
\hline Selisih keseluruhan & \multicolumn{3}{|c|}{ Meningkat $340 \%$} \\
\hline
\end{tabular}


disebabkan oleh meningkatnya suhu pada tahun itu. Hermansah et al (2003) menyatakan bahwa dinamika biomassa melalui monitoring runtuhan sarasah berkolerasi positif dengan suhu dan berkorelasi negatif dengan curah hujan. Dari penelitian yang dilakukan Hermansah dkk pada tahun 2003 di hutan hujan tropis Gunung Gadut kandungan $\mathrm{P}$ tersedia pada kriteria rendah yaitu $2,6 \mathrm{~kg} / \mathrm{ha}$ karena pada hutan hujan tropis banyak berupa pohon yang banyak membutuhkan unsur $P$. Keadaan tersebut diduga kuat mempunyai persamaan dengan keadaan plot penelitian

Perubahan Cadangan Hara di Dalam Tanah tahun 1995 dan 2005 di Plot

Observasi Gajabuih

\section{Perubahan kandungan $\mathrm{P}$ tersedia}

Perubahan P tersedia tanah pada tahun 1995 dan tahun 2005 pada kedalaman 0-20 cm di plot observasi Gajabuih, Gunung Gadut, Padang disajikan pada Tabel 9 dan Gambar 6 dibawah ini. Perubahan $\mathrm{P}$ tersedia tanah ini telah dirubah kedalam bentuk $\mathrm{kg} / \mathrm{ha}$ tanah.

Setelah dikonversikan kandungan $\mathrm{P}$ tersedia dari status hara tanah yang terdapat pada Tabel 3, maka pada tabel 8 dan gambar 4 dalam bentuk grafik dapat dilihat cadangan hara tanah yang ada dalam satuan $\mathrm{kg} / \mathrm{ha}$.

Gajabuih pada tahun 1995. Pada tahun 2005 plot penelitian berubah menjadi semak belukar yang tidak banyak membutuhkan unsur $\mathrm{P}$ melainkan unsur N. Sehingga terjadi peningkatan ketersediaan unsur $\mathrm{P}$ yang berasal dari pelapukan bahan organik. Foth (1998) juga menyatakan bahwa perombakan $800 \mathrm{~kg}$ humus akan menghasilkan dalam mineralisasi sebanyak $40 \mathrm{~kg}$ nitrogen, dengan asumsi bahwa organik tanah mempunyai $5 \%$ nitrogen $(800 \times 0,05)$. Diasumsikan bahwa ratio N: P: S dalam bahan organik adalah $10: 1: 1$, akan menjadi $4 \mathrm{~kg}$ Phosfor, dan $4 \mathrm{~kg}$ Sulfur dimineralisasi. Unsur-unsur hara lain juga dimineralisasi tetapi kemampuan kebanyakan unsur-unsur hara lain hubungannya lebih dekat dengan pelapukan mineral, $\mathrm{pH}$ tanah dan lainnya.

Perubahan Ca-dd

Perubahan Ca-dd tanah pada tahun 1995 dan tahun 2005 pada kedalaman 0-20 cm di plot observasi Gajabuih, Gunung Gadut, Padang disajikan pada Tabel 10 dan Gambar 7 dibawah ini. Perubahan Mg-dd tanah ini telah dirubah kedalam bentuk $\mathrm{kg} / \mathrm{ha}$ tanah.

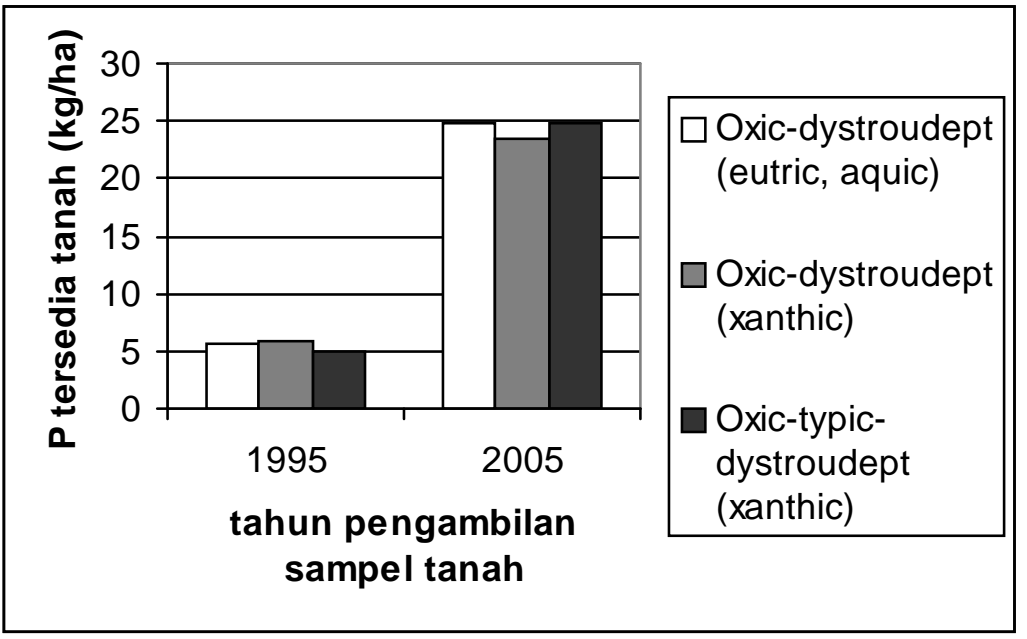

Gambar 6. Perubahan P tersedia tanah Tahun 1995 dan 2005 pada kedalaman $20 \mathrm{~cm}$ di Plot Observasi Gajabuih, Gunung Gadut, Padang 
Tabel 9. Perubahan Ca-dd tanah Tahun 1995 dan 2005 pada kedalaman tanah 0-20 cm di Plot Observasi Gajabuih, Gunung Gadut

\begin{tabular}{lcccc}
\hline \multirow{2}{*}{ Jenis Famili Tanah } & \multicolumn{2}{c}{ Ca-dd (kg/ha) } & \multirow{2}{*}{ perubahan tiap famili } \\
\cline { 2 - 3 } & 1995 & 2005 & tanah \\
\hline Oxic-dystroudept (eutric,aquic) & 946 & 444 & $113 \%$ \\
Oxic-dystroudept (xanthic) & 1416 & 439 & $222 \%$ \\
Oxic-Typic-dystroudept (xanthic) & 1305 & 369 & $253 \%$ \\
\hline Selisih keseluruhan & \multicolumn{3}{c}{ Menurun 196\% } \\
\hline
\end{tabular}

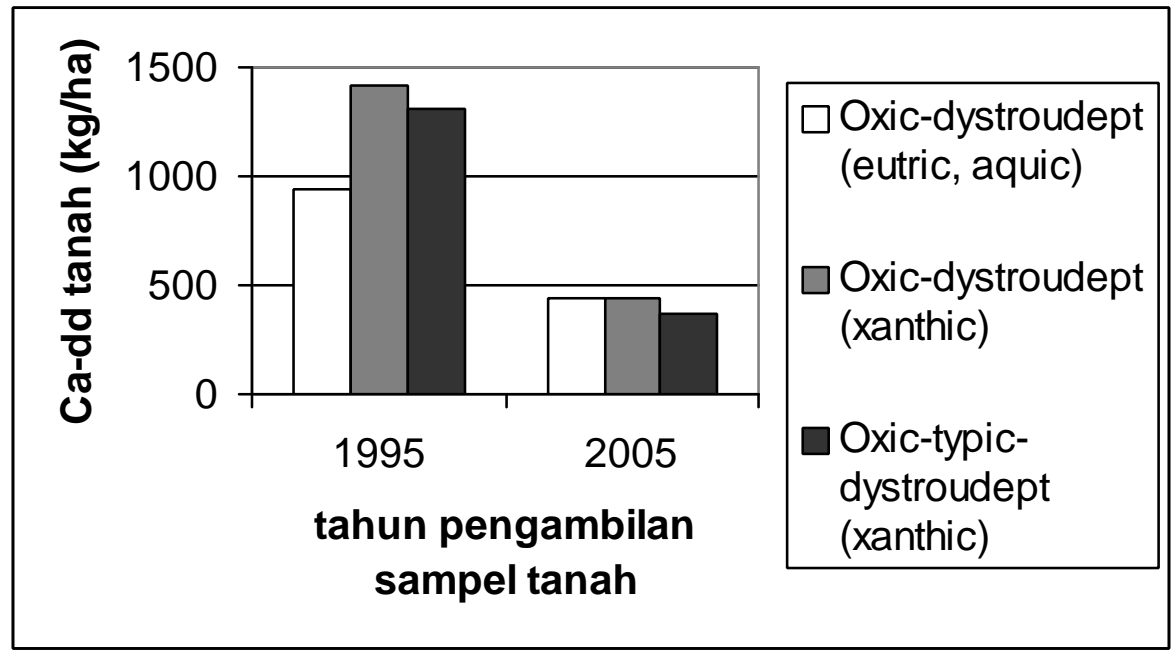

Gambar 7. Perubahan Ca-dd tanah Tahun1995 dan 2005 pada kedalaman tanah 0-20 cm di Plot Observasi Gajabuih, Gunung Gadut, Padang

Setelah dikonversikan Ca-dd dari status hara tanah yang terdapat pada tabel 4, maka pada tabel 10 dan gambar 7 dapat dilihat cadangan Ca-dd tanah yang ada dalam satuan $\mathrm{kg} / \mathrm{ha}$. Dari hasil yang disajikan pada Tabel 9, kandungan Ca-dd mengalami penurunan pada setiap famili tanah. Pada tanah Oxicdystroudept (eutric, aquic) Ca-dd tanah menurun sebesar $113 \%$ selama 10 tahun, pada tanah Oxic-dystroudept (xanthic) Ca-dd tanah menurun sebesar $222 \%$ selama 10 tahun, pada tanah Oxic-Typic-dystroudept (xanthic) Ca-dd tanah menurun sebesar $253 \%$ selama 10 tahun. Kandungan Ca-dd menurun pada tahun 2005 pada lapisan tanah 0-20cm sebesar 196\%.

Penurunan kadar Ca-dd pada plot observasi Gajabuih pada tahun 2005 bila dibandingkan tahun 1995 diduga karena curah hujan yang lebih rendah pada tahun 2005 bila dibandingkan tahun 1995 sehingga kandungan ion Ca yang disumbangkan melalui air hujan ketanah juga lebih rendah. Air hujan yang turun di sekitar daerah Hulu gadut mengandung $\mathrm{Ca}$ yang lebih tinggi karena adanya pengaruh asap PT. Semen Padang (Yuafriza, 1999). Namun karena curah hujan yang turun lebih rendah pada tahun 2005 bila dibandingkan tahun 1995 menyebabkan terjadi penurunan kandungan $\mathrm{Ca}$-dd setelah 10 tahun. Rendahnya Ca-dd pada tahun 2005 juga diduga karena pencucian $\mathrm{Ca}$ kebawah dan erosi yang didukung oleh keadaan topografi yang curam dan landai serta menumpuknya unsur tersebut pada daun karena adanya vegetasi yang menyerap $\mathrm{Ca}$ lebih banyak. 
Rendahnya kandungan Ca-dd pada tahun 2005 diduga juga disebabkan oleh menurunnya jumlah sarasah yang disumbangkan ketanah. Karena plot penelitian yang saat dulu merupakan hutan hujan tropis menyumbangkan puluhan $\mathrm{kg}$ sarasah/ha kedalam tanah. Daun yang merupakan bagian terbesar dari sarasah menyumbangkan jumlah $\mathrm{Ca}$-dd terbesar karena kandungan $\mathrm{Ca}$ lebih tinggi terdapat di daun daripada di dalam tanah (Aflizar,2003). Dari penelitian yang dilakukan
Hermansah et al (2003) di hutan hujan tropis bahwa sumbangan Ca-dd mencapai 125,3 $\mathrm{kg} / \mathrm{ha}$.

Perubahan Mg-dd yang dapat dipertukarkan

Perubahan Mg-dd tanah pada tahun 1995 dan tahun 2005 pada kedalaman 0-20 cm di plot observasi Gajabuih, Gunung Gadut, Padang disajikan pada Tabel 11 dan Gambar 8 dibawah ini. Perubahan Mg-dd tanah ini telah dirubah kedalam bentuk $\mathrm{kg} / \mathrm{ha}$ tanah.

Tabel 10. Perubahan Mg-dd tanah Tahun 1995 dan 2005 pada kedalaman tanah 0-20 cm di Plot Observasi Gajanuih, Gunung Gadut

\begin{tabular}{lccc}
\hline \multirow{2}{*}{ Jenis Famili Tanah } & \multicolumn{2}{c}{ Mg-dd $(\mathrm{kg} / \mathrm{ha})$} & \% \\
\cline { 2 - 3 } & 1995 & 2005 & $\begin{array}{c}\text { Perubahan Tiap famili } \\
\text { tanah }\end{array}$ \\
\hline Oxic-dystroudept (eutric,aquic) & 38,46 & 38,25 & $0,55 \%$ \\
Oxic-dystroudept (xanthic) & 37,44 & 37,38 & $0,16 \%$ \\
Oxic-Typic-dystroudept (xanthic) & 38,16 & 34,74 & $9,84 \%$ \\
\hline Selisih keseluruhan & \multicolumn{3}{c}{ Menurun 3,52\% } \\
\hline
\end{tabular}

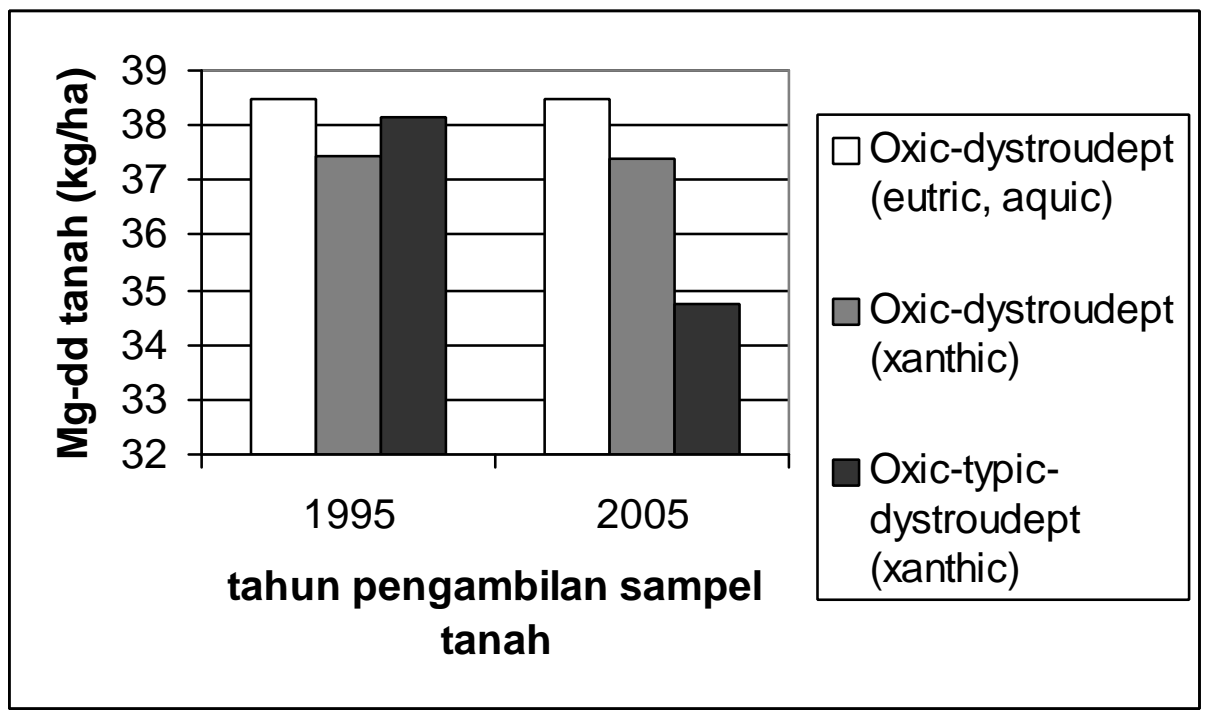

Gambar 8. Perubahan Mg-dd tanah Tahun 1995 dan 2005 pada kedalaman tanah 0-20 cm di Plot Observasi Gajabuih, Gunung Gadut, padang 
Dari hasil yang disajikan pada Tabel 10 kandungan $\mathrm{Mg}$-dd pada kedalaman 0-20 cm pada tiap famili tanah mengalami penurunan. Pada tanah Oxic-dystroudept (eutric, aquic) Mg-dd tanah menurun sebesar $0,55 \%$ selama 10 tahun, pada tanah Oxic-dystroudept (xanthic) Mg-dd tanah menurun sebesar $0,16 \%$ selama 10 tahun, pada tanah Oxic-Typicdystroudept (xanthic) Mg-dd tanah menurun sebesar 9,52\% selama 10 tahun. Kandungan Mg-dd tanah setelah 10 tahun mengalami perubahan yang tidak terlalu mencolok. Pada kedalaman tersebut mengalami penurunan kandungan Mg-dd pada tahun 2005 bila dibandingkan dengan tahun 1995 sebesar $3,52 \%$. Berarti pada plot observasi Gajabuih ini kandungan $\mathrm{Mg}$-dd boleh dikatakan tidak mengalami perubahan karena perubahan yang terjadi kecil.

Air hujan pada kawasan ini juga mengandung ion $\mathrm{Mg}$ yang merupakan pengaruh dari asap pabrik Semen padang. Namun karena curah hujan yang tingi mengakibatkan erosi pada tanah dan juga terjadinya pencucian unsur $\mathrm{Mg}$ sehingga terjadinya sedikit penurunan kandungan Mg-dd tanah pada tahun 2005 didukung dengan sifat dari ion $\mathrm{Mg}^{+2}$ yang mempunyai daya tembus yang rendah pada tanah.

Perubahan K yang dapat dipertukarkan

Perubahan K-dd tanah pada tahun 1995 dan tahun 2005 pada kedalaman 0-20 cm di

Tabel 11. Perubahan K-dd tanah Tahun 1995 dan 2005 pada kedalaman tanah 0-20 cm di Plot Observasi Gajabuih, Gunung Gadut

\begin{tabular}{lccc}
\hline \multirow{1}{*}{ Jenis Famili Tanah } & \multicolumn{2}{c}{ K-dd $(\mathrm{kg} / \mathrm{ha})$} & \multirow{2}{*}{ perubahan tiap famili } \\
\cline { 2 - 3 } & 1995 & 2005 & $\operatorname{tanah}$ \\
\hline Oxic-dystroudept (eutric,aquic) & 18,43 & 53,39 & $190 \%$ \\
Oxic-dystroudept (xanthic) & 18,72 & 37,10 & $98 \%$ \\
Oxic-Typic-dystroudept (xanthic) & 21,09 & 35,15 & $66,6 \%$ \\
\hline Selisih keseluruhan & & & Meningkat 118,2\% \\
\hline
\end{tabular}

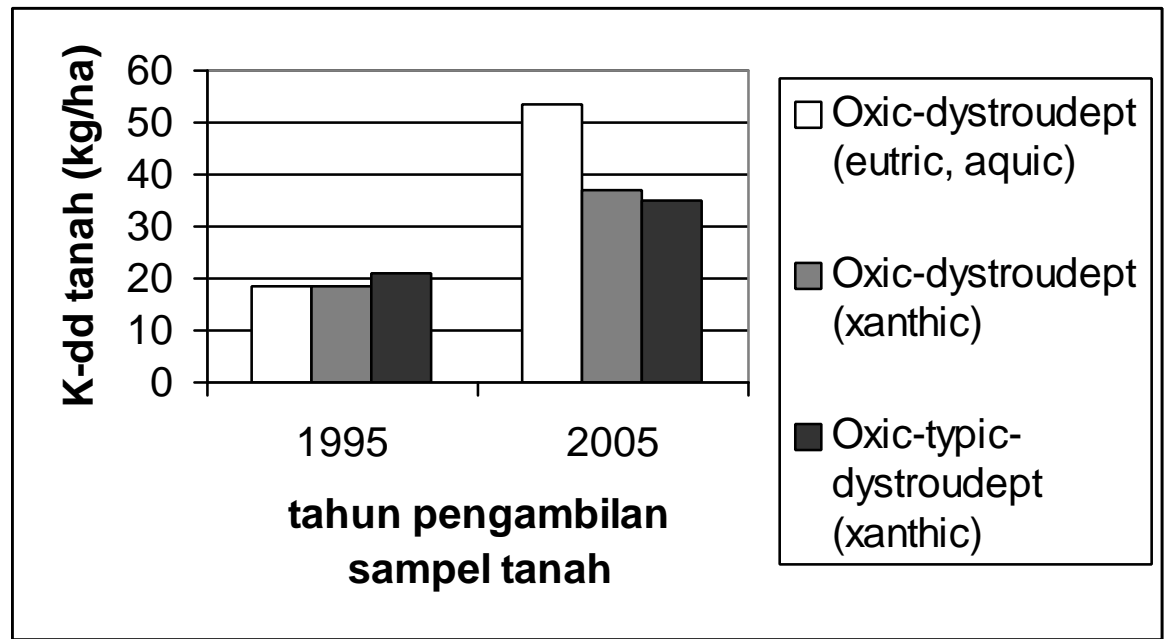

Gambar 9. Perubahan K-dd tanah Tahun 1995 dan 2005 pada kedalaman tanah 0-20 cm di Plot Observasi Gajabuih, Gunung Gadut, Padang 
plot observasi Gajabuih, Gunung Gadut, Padang disajikan pada Tabel 12 dan Gambar 10 dibawah ini. Perubahan K-dd tanah ini telah dirubah kedalam bentuk $\mathrm{kg} / \mathrm{ha}$ tanah.

Dari hasil yang disajikan pada Tabel 11 maka kandungan K-dd tanah pada kedalaman 0-20 $\mathrm{cm}$ mengalami peningkatan pada setiap famili tanah. Pada tanah Oxic-dystroudept (eutric, aquic) K-dd tanah meningkat sebesar $190 \%$ selama 10 tahun, pada tanah Oxicdystroudept (xanthic) K-dd tanah meningkat sebesar 98\% selama 10 tahun, pada tanah Oxic-Typic-dystroudept (xanthic) meningkat sebesar $66,6 \%$ selama 10 tahun. Jadi Setelah dikonversikan K-dd tanah dari status hara tanah yang terdapat pada tabel 6, maka pada tabel 11 dan Gambar 9 dapat dilihat cadangan $\mathrm{K}$-dd tanah dalam satuan $\mathrm{kg} / \mathrm{ha}$. Dapat dilihat bahwa kandungan K-dd tanah pada tahun 2005 meningkat bila dibandingkan pada tahun 1995 pada lapisan 0-20 $\mathrm{cm}$ sebesar 118,2\%.

Peningkatan K-dd pada kawasan ini disebabkan oleh banyaknya vegetasi yang tumbang pada tahun 2002 yang menambah jumlah bahan organik di dalam tanah. Apalagi nisbah $\mathrm{C} / \mathrm{N}$ pada daerah ini pada umumnya pada kriteria sedang sehingga ketersediaan Kdd sedikit lebih tinggi jika dibandingkan pada tahun 1995 karena dekomposisi bahan organik pada kawasan ini belum lanjut. Hakim et al (1986) juga menyatakan rendahnya K-dd dalam tanah juga karena adanya akumulasi oleh mikroorganisme sebagai sumber energi dalam melakukan perombakan dimana mikroorganisme menggunakan $\mathrm{K}$ sebagai pembentuk sel-sel baru.

Tabel 12. Perubahan Na-dd tanahTahun 1995 dan 2005 pada kedalaman tanah 0-20 cm di plot Observasi Gajabuih, Gunung Gadut

\begin{tabular}{lccc}
\hline \multirow{2}{*}{\multicolumn{1}{c}{ Jenis Famili Tanah }} & \multicolumn{2}{c}{ Na-dd (kg/ha) } & \multirow{2}{*}{$\begin{array}{c}\text { perubahan tiap famili } \\
\text { tanah }\end{array}$} \\
\cline { 2 - 3 } & 1995 & 2005 & $810 \%$ \\
Oxic-dystroudept (eutric,aquic) & 5,17 & 47,05 & $554 \%$ \\
Oxic-dystroudept (xanthic) & 5,06 & 33,11 & $500 \%$ \\
Oxic-Typic-dystroudept & 5,94 & 35,69 & \\
(xanthic) & \multicolumn{3}{c}{ Meningkat 621\% } \\
\hline Selisih keseluruhan & \multicolumn{4}{c}{} \\
\hline
\end{tabular}

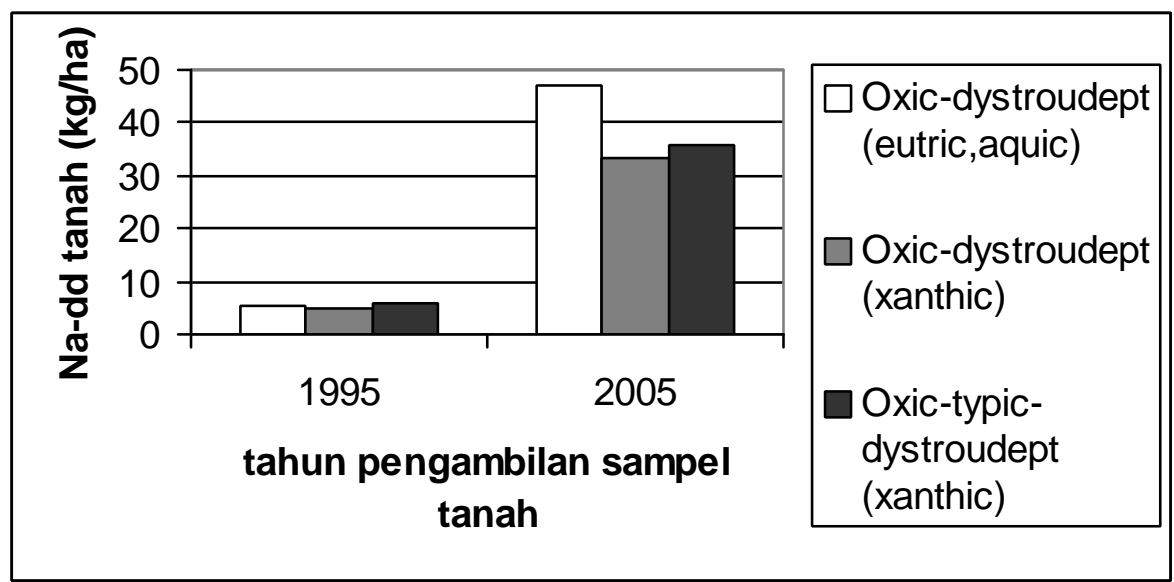

Gambar 10. Perubahan Na-dd Tanah Tahun 1995 dan 2005 pada kedalaman tanah 0-20 cm di Plot Observasi Gajabuih, Gunung Gadut, Padang 
Perubahan Na yang dapat dipertukarkan

Perubahan Na-dd tanah pada tahun 1995 dan tahun 2005 pada kedalaman 0-20 $\mathrm{cm}$ di plot observasi Gajabuih, Gunung Gadut, Padang disajikan pada Tabel 12 dan Gambar 10 dibawah ini. Perubahan Na-dd tanah ini telah dirubah kedalam bentuk $\mathrm{kg} / \mathrm{ha}$ tanah.

Setelah dikonversikan Na-dd dari status hara tanah yang terdapat pada tabel 7 , maka pada tabel 13 dan gambar 10 dapat dilihat cadangan Na-dd tanah yang ada dalam satuan $\mathrm{kg} / \mathrm{ha}$. Dari hasil yang disajikan pada Tabel 13 kandungan Na-dd tanah mengalami peningkatan pada setiap famili tanah. Pada tanah Oxic-dystroudept (eutric, aquic) Na-dd tanah meningkat sebesar $810 \%$ selama 10 tahun, pada tanah Oxic-dystroudept (xanthic) Na-dd tanah meningkat sebesar 554\% selama 10 tahun, pada tanah Oxic-Typic-dystroudept (xanthic) Na-dd tanah meningkat sebesar $500 \%$ selama 10 tahun. Kandungan Na-dd tanah pada tahun 2005 lebih besar bila dibandingkan tahun 1995 atau meningkat setelah 10 tahun pada kedalaman $0-20 \mathrm{~cm}$ sebesar $621 \%$.

Kandungan Na-dd pada tahun 2005 lebih tinggi bila dibandingkan pada tahun 1995. Hal ini diduga karena curah hujan pada kawasan ini mengandung ion $\mathrm{Na}$ yang berasal dari penguapan air laut dan dibawa oleh angin kekawasan Gunung Gadut. Sejalan dari waktu kewaktu menyebabkan $\mathrm{Na}$ semakin tinggi pada kawasan ini.

\section{KESIMPULAN DAN SARAN}

Kesimpulan

1. Terjadi perubahan status hara tanah setelah 10 tahun (tahun 1995 dan tahun 2005). Walaupun tidak berbeda nyata namun secara kriteria dan angka terjadi perubahan pada setiap famili tanah.

2. Kandungan $\mathrm{P}$ tersedia didalam tanah meningkat sebesar 340\%, kandungan Nadd meningkat sebesar $621 \%$, kandungan Mg-dd tanah menurun sebesar 3,52\%, kandungan Ca-dd menurun sebesar 196\%, kandungan K-dd meningkat sebesar
$118,2 \%$, nisbah $\mathrm{C} / \mathrm{N}$ tanah menurun sebesar $29,06 \%$.

3. Daerah plot penelitian Bukit gajabuih Padang memiliki reaksi tanah atau $\mathrm{pH}$ yang rendah (masam).

4. Perubahan keanekaragaman vegetasi yang berada di Bukit Gajabuih Padang mempengaruhi karakteristik kesuburan tanah.

Saran

Adapun saran dari penulis adalah: 1.kajian dinamika karakteristik tanah dengan hubungannya dengan aktifitas penggunaan lahan sangat diperlukan. 2.Penelitian lanjutan untuk memahami perubahan dinamika tanah dengan hubungannya dengan perubahan vegetasi pada plot penelitianini sangat diperlukan.

\section{DAFTAR PUSTAKA}

Alfizar. 2003. Sarasah dan karakteristik Fisika dan unsur hara tanah hutan hujan tropika super basah di Pinangpinang. Tesis Pasca Sarjana Pertanian Universitas Andalas. Padang. 141 hal.

Darwono. 2005. Penebanan hutan dan akibatnya terhadap duania. www. http. Hutan Hujan tropika. Acses : 30 Januari 2006.

Ewussie, J.Y. 1990. Pengantar t _i tropika. ITB. Bandung. 369 hal.

Fiantis, Dian. 2004. Klasifikasi dan Morfologi Tanah. Universitas Andalas. Padang. 300 hal.

Foth. 1998. Dasar-dasar IImu Tanah. Institut Pertanian Bogor. Bogor. 580

Hakim, N; M.Y. Nyakpa, A.M. Lubis, S.G. Nugroho, M.R. Saul, M.A. Diha, G.B. Hong dan Bailey. 1986. Dasar-dasar Ilmu Tanah. Universitas Lampung. Lampung. 488 hal.

Hardjowigeno. 1987. Ilmu Tanah. Mediyatan Sarana Prakarsa. Jakarta. 219 hal.

Hakim, Nurhajati. 2003. Penuntun Ringkas Pratikum Dasar-dasar IImu Tanah. Universitas Andalas. Padang. 30 hal. 
Hermansah; T. Masunaga, Wakatsaki, and Alfizar. 2003. Dinamics of litter production and its quality in relation to climatic factor in super wet tropical rain forest, West Sumatra, Indonesia. Tropics 12 (2). The Japan Society of Tropical Ekology. Japan. Pp 131 146.

Kubota, Daisutki. 1999. Soil quality characterization in relation to tree species in Tropical rain forest West Sumatra. The united Graduated School of Agricultur Science, Tottory University. Japan. 93 hal.

Masunaga, T; D.Kubota, M. Hotta, T. Wakatsuki. 1997. Nutritional characteristics of mineral elements in tree species of tropical rain forest West Sumatra. Soil. Sci. Plant. Nutr 4 (3). Japan. Pp 405-418.

Mohsin; A. Saheed, D. Kubota, T. Masunaga, T. Wakatsuki. 1997. Soil degradation during the period 1967-1995 in Banglangdesh. Soil. Sci. Plant. Nutr 43 (4). Japan. PP 879-890.

Nyakpa, M, Y; Lubis A. M, Pulung, Amran, Munawar, G.B. Hong, N. Hakim. 1998. Kesuburan Tanah. Universitas lampung. Lampung. 258 hal.

Ogino, K; M. Hotta, R. Tamin, T. Yoneda. 1984. Forest ecologi and flora of Gunung Gadut area, Forest ecologi and flora of Gunung Gadut West Sumatra. Sumatra Nature Study, Kyoto. Japan. 220 hal.

Pampasit, S; S. Khamyong, G. Brealmann, I. Minomiya and K. Ogino. 2000. $M$ ineral element acummullation in soil and trees in tropical hill evergreen forest. Northern Thailand. Tropics 9 (4). Japan. Pp 275-286.
Rusman, Bujang. 1999. Konservasi Tanah dan Air. Universitas Andalas. Padang. 182 hal.

Rao. N. S. S. 1982. Biofertilizer in agriculture. Oxford and IBH Publishing Co. New delhi. Bombay, Calcuta. 125 hal

Rosmarkam dan Yuwono. 2002. IImu Kesuburan Tanah. Kanisius. Yogyakarta. 214 hal

Sanchez, P. A. 1992. Sifat-sifat dan pengelolaan tanah tropika. Edisi 1 dan 2, Institut Teknologi Bandung. Bandung. 120 hal.

Saryono, H. 2002. Pengelolaan hutan, tanah dan air dalam perspektif Al-quran. Pustaka Al Husna Baru. Jakarta. 260

Soedarsono, J. 1982. Mikrobiologi Tanah. Departemen Mikrobiologi Fakultas Pertanian Universitas Gajah Mada. Yogyakarta. 65 hal

Tan, K.H. 1991. Dasar-dasar kimia tanah. Gadjah mada University Press Yogyakarta. 299 hal.

Tjaswono. 2004. Dasar-dasar Klimatologi. Institut Teknologi Bandung. Bandung. 198 hal.

Vitausek, P.M. 1984. Literfall nutrient cycling and nutrient limitation in tropical F orest. Ekology. PP 285-298.

Winarto, M. 2003. Produktivitas vegetasi hutan hujan Tropis. Makalah Pengantar Falsafah Sains (PPS702). Institut Pertanian Bogor. Bogor. Poster 8 November 2003.

Yuafriza. 1999. Ciri Kimia dan Kualitas Air Hujan serta Pengaruhnya terhadap Kation Basa di Lapisan Atas pada lereng bawah G. Gaduik Padang. Fakultas Pertanian Universitas Andalas. Padang. 58 hal 